Int. J. Dev. Biol. 51: 371-378 (2007)

doi: $10.1387 / \mathrm{ijdb} .072280 \mathrm{hb}$

Original Article

\title{
Neural differentiation from human embryonic stem cells in a defined adherent culture condition
}

\author{
HOSSEIN BAHARVAND* ${ }^{*}{ }^{1}$, NARGES-ZARE MEHRJARDI ${ }^{1}$, MARYAM HATAMI ${ }^{1}$, SAHAR KIANI ${ }^{1}$, \\ MAHENDRA RAO ${ }^{2}$ and MAHDI-MONTAZER HAGHIGHI ${ }^{1}$ \\ ${ }^{1}$ Department of Stem Cells, Royan Institute, Tehran, Iran and ${ }^{2}$ Stem Cells and Regenerative Medicine, Invitrogen, Carlsbad, CA, USA
}

\begin{abstract}
Understanding how to direct human embryonic stem cells (hESCs) toward a specific lineage pathway and generate appropriate cell types robustly is very important, not only for the study of developmental biology but also for potentially using these cells to treat human diseases. In this study, hESCs were differentiated to the neural lineage in defined adherent culture by retinoic acid and basic fibroblast growth factor. Our protocol seems to recapitulate the early steps of nervous system development in vivo in that undifferentiated hESCs organized into rosettes and then neural tube-like structures are formed. Differentiating cells expressed neuroectodermal and mature neuron markers during neural plate and tube formation and maturation, as shown by reverse transcriptase-PCR. More than $\mathbf{9 0} \%$ of differentiated cells expressed additional neuronspecific antigens (i.e., tubulin-III, MAP-2, synaptophysin and neurofilament protein). Ultrastructural analysis of differentiating neural tube-like structures in three dimensional collagen scaffolds showed an ependymal-like layer and neural structure with typical synapses. These results provide a simple and relatively defined system for differentiation of hESCs to neural lineages, particularly neurons with typical cellular, molecular and ultrastuctureal markers. The culture of neural precursor cells in a collagen scaffold may provide a new approach for the repair of spinal cord injury.
\end{abstract}

KEY WORDS: defined condition, human embryonic stem cell, neural differentiation, ultrastructure

\section{Introduction}

Human embryonic stem cells (hESCs) are derived from preimplantation embryos and retain the developmental potency of embryonic founder cells, being able to differentiate into cells and tissues of all three germ layers in vitro and in vivo (for review see Baharvand, 2006). The isolation and culture of hESCs has sparked public enthusiasm about the potential application of these cells in understanding early human development and developing assays of pharmacology and toxicology and in developing cell therapy in a wide range of diseases. Differentiating hESC cultures provide a novel model system to elucidate the molecular signals required for the development of various lineages. Human ESCs can be expanded to large numbers under a stable genetic background for a long period and while retaining their differentiation potentials (Reubinoff et al., 2000, Thomson et al., 1998). This is particularly important for transplantation therapies, because hESCs promise an almost unlimited supply of specific cell types. However, directing hESC differentiation along specific lineage pathways remains a challenge. The clinical application of hESCs requires the generation of highly purified donor cells for specific tissues or organs.
For neural differentiation of hESCs, most methods available so far are based on the initial formation of cell aggregation or embryoid bodies (EBs) in the presence of serum or coculture of hESCs with specific stromal cell lines (Carpenter et al., 2001, Perrier et al., 2004, Zhang et al., 2001) or using conditioned medium from the human hepatocellular carcinoma HepG2 cell line (Shin et al., 2006). In the first instance, hESCs were initially differentiated in suspension cultures to form EBs, which often contain cells of all three germ layers; clusters of neural cells are surrounded by flat non-neural cells (Carpenter et al., 2001, Zhang et al., 2001). Moreover, due to the complexity of multicellular aggregates, it is difficult to use this system for studying signaling pathways essential for the neural differentiation. In the latter case, the effect of stromal cells is attributed to an undefined neural-inducing activity (Perrier et al., 2004). In mouse ESCs, neuroectoderm differentiation has been achieved in an adherent monoculture system in a serum-free medium, without multicellular aggregation or coculture

Abbreviations used in this paper: bFGF, basic fibroblast growth factor; hESC, human embryonic stem cell; KSR, knock-out serum replacement; MEF, mouse embryonic fibroblast; RA, retinoic acid. 


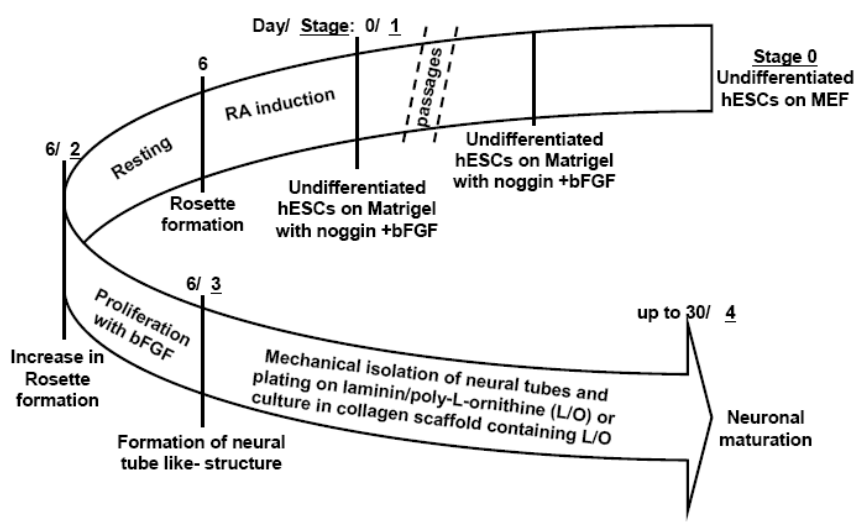

Fig. 1. Schematic illustration outlining the derivation of mature neurons and transplantable neuronal precursors from human embryonic stem cells (hESCs). bFGF, basic fibroblast growth factor; MEF, mouse embryonic fibroblast; $R A$, retinoic acid.

with other cell types (Ying et al., 2003). This monolayer culture regimen enables us to directly visualize the process of neural conversion. In addition, because the process is in a chemically defined medium, it provides a good system in the future to investigate signaling pathways in controlling the ESC neural differentiation.

Here, we show that adherent cultures of hESCs in serum-free medium supplemented with retinoic acid (RA) and basic fibroblast growth factor (bFGF) gave rise to a enriched neural population $(>90 \%)$ by mechanical isolation and replating of neural tube-like structures. Characterization of this population showed appropriate expression of phe-

Fig. 2. Characterization human embryonic stem cell (hESC)-derived neural progenitors and neurons by phase microscopy and immunocytochemistry. Phase contrast photomicrographs of a colony of hESC (Royan H5) grown on mitomycin $C$-treated mouse embryonic fibroblasts (stage 0) (A). Cells demonstrate a typical undifferentiated morphology with a clearborder. A colony of hESC grown on Matrigel in medium supplemented with bFGF and noggin and in the absence of KSR (stage 1) (B). Typical rosette-neural progenitors appeared at, during and after retinoic acid treatment $(\mathbf{C})$ and are positive for nestin antibody staining (stage 2) (D,E). The neural tube-like structures (F) isolated mechanically under an inverted microscope and cultured on laminin/poly-L-ornithine (stage 4). By $14 d$ after plating, a large number of cells in the outgrowth area formed networks with their processes (G). Immunostaining indicated that the majority of differentiated cells were positive for $\beta$-tubulin III (H), microtubuleassociate protein-2 (MAP-2) (I), synaptophysin (J) and neurofilament protein (K). The red color represents nucleicounterstained with propidium iodide. The stages are shown in parenthesis. notype specific markers and an appropriate gene expression profile. Moreover, ultrastructural analysis of differentiated cells in three dimensional collagen scaffolds showed formation of structural networks of synaptically coupled cells.

\section{Results}

\section{Differentiation of neuronal cells and expression of specific markers}

Human ESCs originally were cultured on a MEF feeder layer in the presence of fetal calf serum (stage 0, Fig. 2A) and then were cultured on matrigel in feeder-free and serum free conditions for several passages (stage 1, Fig. 2B). Our protocol of neural differentiation in defined adherent culture comprises four stages. Stage 1 was feeder-free hESC culture on Matrigel-coated culture plates in the presence of noggin, bFGF and $20 \%$ KSR (Fig. 2B). In this condition, the cell line maintained its distinct stem cell morphology and remained Oct4- and SSEA3- and SSEA4-positive (data not shown). When the cells were almost confluent (4-5 days), they were cultured in same medium without noggin and bFGF but supplemented with RA and then further cultured without
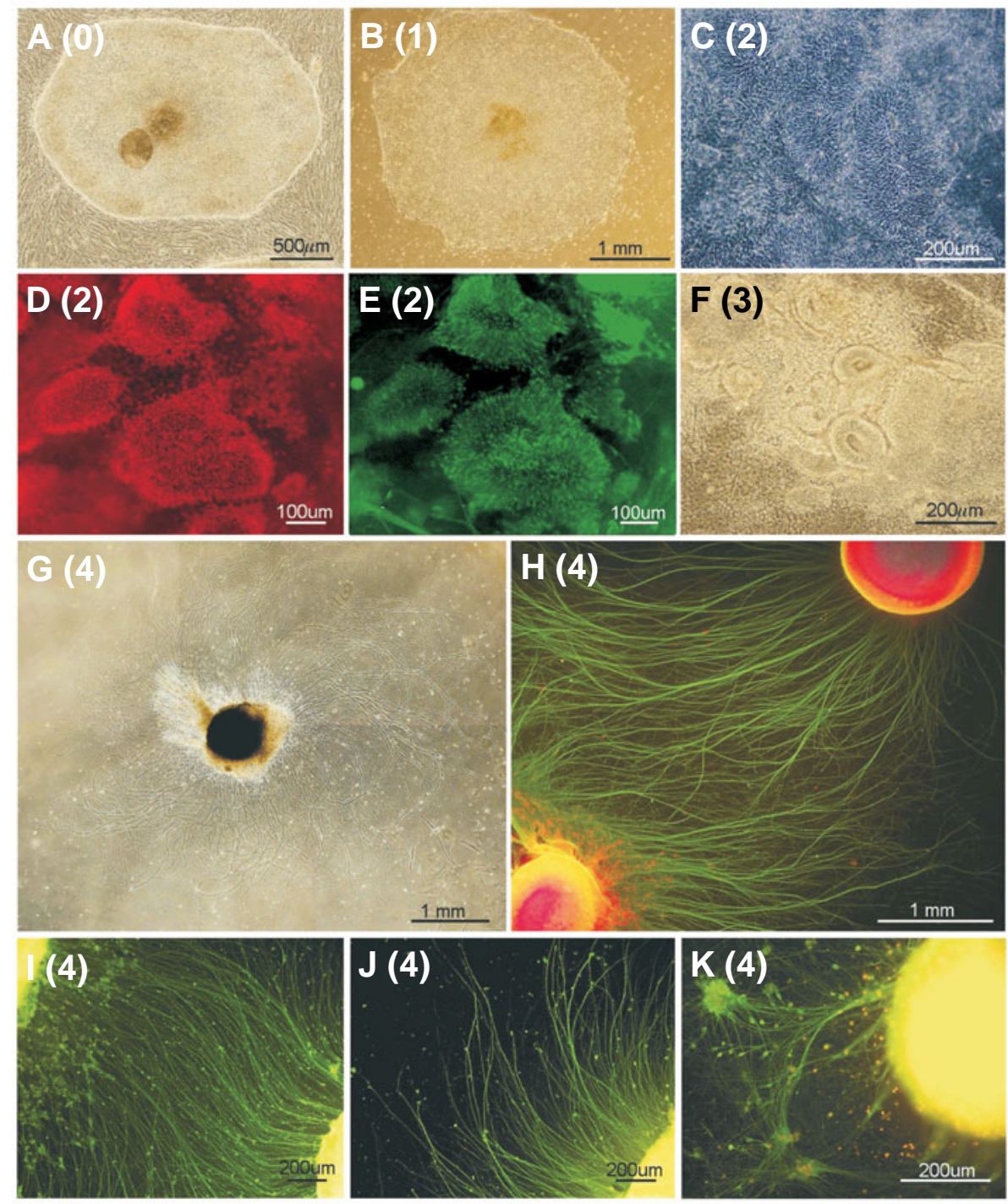
RA (stage 2). During the initial induction stage, the cells exhibited the first sign of neural differentiation, i.e., the appearance of columnar cells forming rosettes (Fig. 2C). The cells expressed nestin, Sox1, Sox3, Pax6, Nkx6.1, Nkx2.2,Mnr2, Lim2, Lim3 and HB9 (as shown by RT-PCR, stage 2, Fig. 3), which most of them are neuroectodermal markers expressed during neural plate and tube formation (Pevny et al., 1998). Immunocytochemical analyses revealed that the rosette cells were positive for nestin (stage 2, Fig. 2D and 2E). The neural progenitors could be maintained at a relatively high dividing rate and the columnar cells organized into neural tube-like structures with lumens when bFGF was added to the medium (stage 3, Fig. 2F). In addition to the genes detected above, a subset of the cells at this stage expressed Olig2 (Fig. 3). We isolated hESC-generated neural tube-like structures with a pipette and differentiation of the hESC-derived neural tubes induced by withdrawal of bFGF and plating on a laminin/poly-Lornithine substrate (stage 4). Within a few days, numerous processes grew out from the neural tube, giving the appearance of a starburst. By 30 days after plating processes emanating from the neural tubes had formed prominent fiber bundles (Fig. 2G). Few small migrating cells were seen in close association with the fibers. Immunofluorescence analyses of the differentiated cultures revealed that the vast majority of cells in the outgrowth areas expressed neural markers [ $\beta$-tubulin III (97.3 2 2.1, Fig. $2 \mathrm{H})$, MAP-

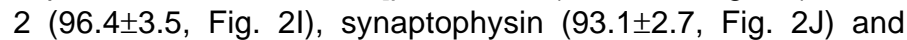
neurofilament protein $(91.8 \pm 1.6$, Fig. $2 \mathrm{~K})$ ]. These percents were obtained after mechanical isolation of neural tube-like structures and differentiation. RT-PCR analysis of 30-day differentiated cells demonstrated that transcripts of nestin, Sox1, Nkx6.1, Nkx2.2, Mnr2 and $\mathrm{Hb} 9$ were expressed by the cells at stage 4 (Fig. 3). RTPCR results also showed that Oct4 expression was retained longer during neural differentiation than the other canonical hESC marker, Nanog. Moreover, transcripts of myelin binding protein (MBP), a marker of myelin expression, were not detected by RTPCR (data not shown).

\section{Ultrastructure of differentiated neurons}

Basophilic clumps (Nissl bodies) appeared throughout the cytoplasm as shown by Cresyl violet acetate dye (sigma; C5042) (Fig. 4A). Cultured neural tube-like structures displayed very long neurite extensions in collagen scaffolds and sent their process together (Fig. 4B). The micrographs of hESC-derived differentiated neural cells are shown in Figure 4 (D-K). In the center of neural tube-like structure was an ependymal-like layer, based on the presence of microvilli, centrosomes, microtubules, tight junctions and the columnar shape of the cells (Fig. 4C-4E). The cell bodies contained a large, euchromatic nucleus with one to three prominent nucleoli (Fig. 4F-4H). The perinuclear cytoplasm revealed abundant rough endoplasmic reticulum ( $r E R)$ and free ribosomes, which constitute the Nissl bodies, a feature consistent with its protein synthetic activity. The perinuclear cytoplasm also contained numerous mitochondria, a large perinuclear Golgi apparatus, lysosomes, microtubules and neurofilaments (intermediate filaments). The axoplasm, lacked rER but contained short segments of SER and long and slender mitochondria. In cross-section, the neurofilaments were spaced a uniform distance apart through the axoplasm. Microtubules were also numerous, but less uniformly distributed, than the neurofilaments. The appearance of synapses was a definite sign of neuronal identity. There were some glial cells with several unmyelinated axons occupying deep recesses on their surface; however, the myelinated axons were not observed (Fig. 4I). There were some immature and mature synaptic contacts with many distinct preand postsynaptic densities and synaptic vesicles (Fig. 4J, 4K).

\section{Discussion}

This work demonstrates that neuronal cells with typical cellular, molecular and ultrastuctureal markers can differentiate efficiently from hESCs using a defined adherent culture protocol with RA and bFGF. Differentiated neural tube-like structures displayed an ependymal-like layer, neuronal structure and typical synapses in a three dimensional collagen scaffold. Although, relatively little is known about dissimilarities in developmental competencies between hESC lines (Allegrucci et al., 2004), this protocol may be useful for neural differentiation of most of other hESC lines as we see in other reports (Nat et al., 2007). Most studies investigating mouse and human ESC differentiation to neural progenitors have used methods involving cell aggregation or EB formation. EB formation in serum containing medium included cells differentiated into neuroepithelial cells (Schuldiner et al., 2000, Zhang et al., 2001), but also led to stochastic differentiation yielding multiple cell lineages, thus limiting the overall yield of the desired neuroepithelial cells (Dang et al., 2002). Dang et al., (2002) compared EB differentiation cultures to adherent differentiation culture and reported that adherent differentiation seemed to exclude cell differentiation toward hematopoietic development. Ying et al., (2003) used adherent differentiation with mouse ESCs and obtained efficient neural commitment. Moreover, Li et al., (2005) demonstrated that early neuroepithelial cells can be efficiently generated from hESCs in serum-free medium without any growth factors or morphogens, in suspension cultures (in the first stage of their protocol). Subsequently the cells proliferated in bFGF enriched medium. Here, we adapted these protocols for the production of hESC-derived neural cells adherent culture. In the same manner as Li et al., (2005) we did not use bone morphogenetic protein (BMP) inhibitors, such as noggin for neural induction. It was shown that adherent cultures of hESCs in serum deprived

Fig. 3. Temporal expression pattern of genes by reverse transcription polymerase chain reaction (RT-PCR). Stages 0 to 4 are explained in Materials and Methods and Fig. 1. The samples of stage 4 were harvested 30 days after replating of neural tube-like structures. Genomic contamination was monitored by sample prepared without reverse transcription $\left(R T^{-}\right)$.

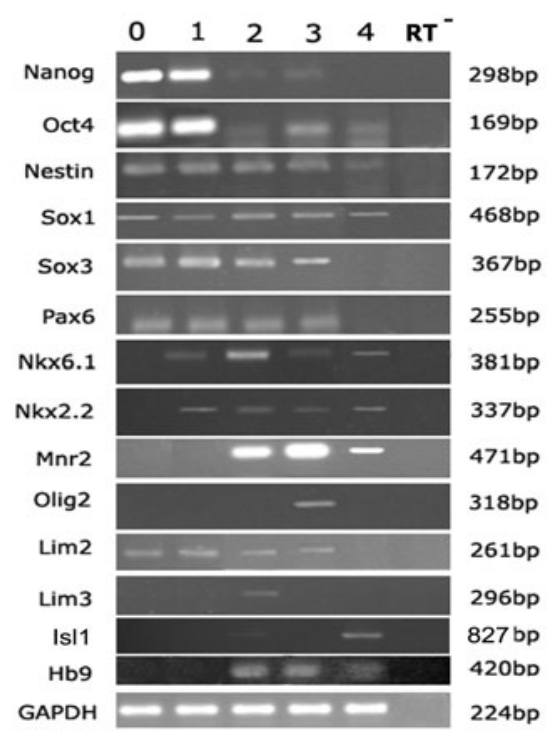



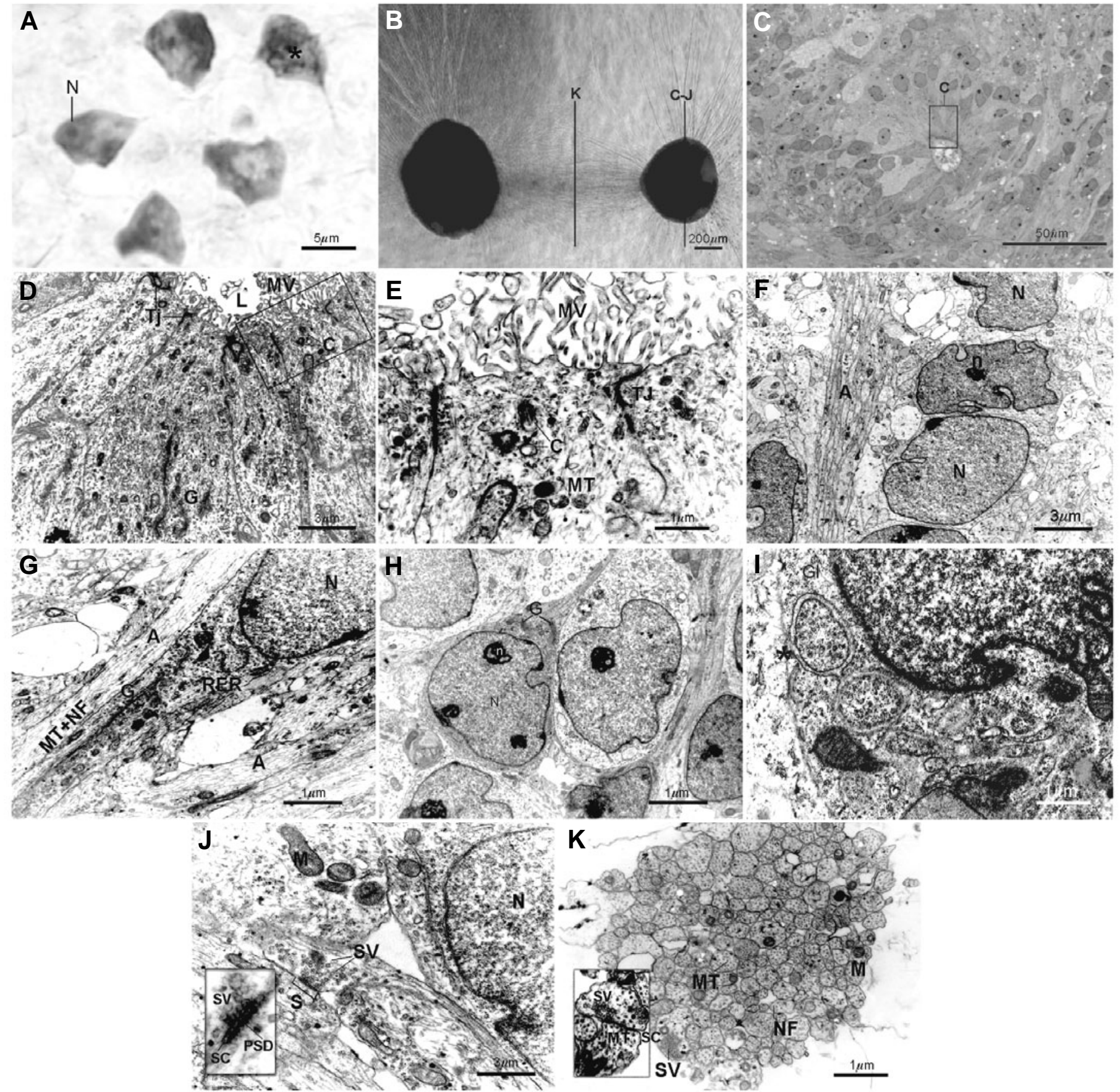

Fig. 4. Light microscopy (A-C) and electron micrograph of the differentiated neurons (C-K). (A) Basophilic clumps (Niss/ bodies: *) appeared throughout the cytoplasm as shown by Cresyl violet acetate dye. (B) Differentiated neural tube-like structures in collagen scaffolds displayed very long neurite extensions. (C) The semithin section of differentiated hESC-derived neural tube. The labeled area in (C) appears to be an ependymal layer based on the presence of microvilli (MV), tight junctions (TJ) and the columnar shape of the cells (magnified in D). (E) A higher magnification of the labeled area in (D) showing centrosomes (C), microtubules (MT), neurofilaments (NF) and TJ. (F-H) The perinuclear cytoplasm also contains numerous mitochondria (M), a large perinuclear Golgi apparatus (G), MT and NF. The axoplasm lacked rough endoplasmic reticulum (rER) but contained short segments of smooth endoplasmic reticulum (sER) and long and slender mitochondria. In cross-section, the NFs were spaced a uniform distance apart through the axoplasm. Microtubules were also numerous, but less uniformly distributed than the NFs. The cell body contained a large, euchromatic nucleus (N) with one to three prominent nucleoli (n). (I) There were some glial cells (Gl) with several unmyelinated axons occupying deep recesses $\left(^{*}\right)$ on their surface. However, myelinated axons were not observed. (J,K) Some immature and mature synaptic contacts with many distinct pre and postsynaptic densities and synaptic vesicles were observed. Note the synaptic area (S), the cluster of synaptic vesicles (SV), synaptic cleft (SC) and postsynaptic density (PSD). 
medium with $\mathrm{N} 2$ and B27 accompany with conditioned medium of human hepatocellular carcinoma (HepG2) (Shin et al., 2006) and/or noggin (Gerrard et al., 2005, Yao et al., 2006) gave rise to a rosette enriched population, respectively. More recently, Nat et al., (2007) by adapting of Ying et al., (2003) protocol used six hESC lines to evaluate defined conditions for neural differentiation in suspension and adherent culture systems in serumand feeder-free condition to induce neural fate decisions in hESCs. However, these protocols cultured their hESCs on feeder cells, or isolated immediately before differentiation and/ or produced neuroepithelial cells only, while our hESCs were cultured feeder free and allowed to differentiate in serum-free medium as adherent cultures in the presence of RA and bFGF. In contrast to the method adopted for single cell differentiation of mouse ESCs (Ying et al., 2003) and isolated clumps of hESCs (Nat et al., 2007) we also maintained cell-to-cell contact of hESCs in the adherent system, on a matrigel matrix. In these conditions, the hESCs survived in feeder-free conditions and without plating the cells as clusters. Our findings indicate efficient production of neural cells of relatively high purity. Moreover, the adherent culture protocol facilitates visualization of the process of neural conversion. Serum deprivation apparently is crucial for ectodermal derivation (Tropepe et al., 2001) and removal of the feeder cell layer produced homogenous rosette formation from homogenous spread of cells in adherent culture conditions.

Our protocol seems to recapitulate the early steps of the nervous system development in vivo in that undifferentiated hESCs become more compact and then neural tube-like structures are formed. This could provide an experimental tool to study factors affecting human neural tube formation under controlled conditions (Gerrard et al., 2005, Ying et al., 2003). In line with the procedure of Li et al., (2005), Yao et al., (2006) and $\mathrm{Li}$ and Zhang, (2006), we did not use bFGF in the first step of neural induction of hESCs. We used this growth factor for the proliferation stage of neural progenitor cells, in our system (stage 3). RA and bFGF treatment induce caudalization of neural tissues and/or motoneuron specification and inhibit the production of rostral central nervous system tissues (Mizuseki et al., 2003, Wichterle et al., 2002). Retinoic acid treatment of EBs results in robust neuronal differentiation in a reproducible way (Bain et al., 1996). Hence, it is most widely used for neuronal differentiation from ESCs including hESCs. In contrast, it was suggested that neuroepithelial formation may be a default process during neural differentiation of ESCs in vitro (Liour et al., 2006). Nat et al., (2007) have also shown that the addition of RA is not mandatory for the induction of neuroepithelial phenotype. Further, RA in concert with bFGF signaling leads to the differentiation of spinal motor neurons (Mizuseki et al., 2003, Wichterle et al., 2002). The inhibition of the FGF signaling pathway suppresses the expression of the RA receptor and the overexpression of RARa, the RA receptor, restores the effects of FGF, demonstrating the interaction between the RA and FGF pathways in specifying the rostrocaudal neural axis and suggesting that RARa is a direct target for the FGF signaling pathway (Shiotsugu et al., 2004). In contrast, bFGF has also been shown to inhibit RA signaling and thus motoneuron differentiation (Cavodeassi et al., 1999, Meirmanov et al., 2003). Moreover, bFGF alone induced long-term cultured fetal human neural stem cells to form cholinergic neurons (Wu et al., 2002), suggesting that bFGF may also be an effective growth factor for in vitro differentiation to human motor neurons. Basic FGF is a survival and proliferation factor for early neural precursor cells (Okabe et al., 1996). FGF might act by antagonizing the BMP signal pathway indirectly, or by directly inducing specific transcription factors, which determine neuroectoderm induction and inhibit mesoderm differentiation (Chen et al., 2003). Thus, we predicted that subjecting adherent human neuroepithelial cell cultures to these two factors would lead to motor neuron phenotypes. Our RT-PCR results showed that the expression of nestin, Sox1, Nkx6.1, Nkx2.2, Mnr2 and Hb9 up to stage 4. Lim3 and oligo2 were expressed only at stage 2 (after treatment with RA) and stage 3 (after treatment with bFGF), respectively and $\mathrm{Hb} 9$ and Mnr2 initiated to express at stage 2. However, the expression of Sox3, Pax6 and Lim2 was not detectable after 30 days at stage 4 . SOX1 and SOX3 are conservative criteria for neuroepithelial characterization (Shin et al., 2006) and two homeodomain proteins, Pax6 and Nkx6.1 and basic helix-loop-helix protein, Olig2, are the markers of progenitor cells of motor neurons (Mizuguchi et al., 2001, Novitch et al., 2001, Sander et al., 2000); their combined activities direct the expression of downstream transcription factors, notably the homeodomain proteins IsI1 and HB9, that consolidate the identity of postmitotic motoneurons (Arber et al., 1999). In feeder-free culture of hESC, the expression of Nkx6.1, Nkx2.2 and Lim3 were observed; however, these were not detected in hESCs on a feeder layer. This could be due to the application of the BMP antagonist, noggin in our feeder free undifferentiated hESC culture. The addition of noggin into the medium might have blocked the BMP signaling and stimulated expression of some neural progenitor genes (Itsykson et al., 2005).

It has been reported that Oct4, the POU-domain transcription factor encoded by Pou5 1 , may be required for neurogenesis (Shimozaki et al., 2003). Our RT-PCR results showed which Oct4 expression was retained longer during neural differentiation than the other hESC marker, Nanog and decreased slowly. This is consistent with previous published reports (Gerrard et al., 2005, Nat et al., 2007, Perrier et al., 2004, Shimozaki et al., 2003) suggesting that transiently sustained levels of Oct4 expression may be required for in vitro differentiation of hESCs into neural lineages because rapid downregulation of Oct4 expression in ESCs might have promoted the formation of primitive endoderm (Hay et al., 2004, Niwa et al., 2000).

Further, ultrastructural analysis of differentiated cells in three dimensional collagen scaffolds showed formation of structural networks of synaptically coupled cells. The immobilization of neural cells in three-dimensional scaffolds has been the subject of some previous work. Primary neural cells, neuronal cell lines, and/or glial cells have been immobilized in a wide variety of matrices including polyacrylamide hydrogels, agarose and collagen gel and used for treatment of spinal cord injury (Joosten et al., 2004, Klapka and Muller, 2006, O'Shaughnessy et al., 2003).

Taken together, the results reported here provide a simple and relatively defined system for differentiation of hESCs to neural lineages, particularly neurons with typical cellular, molecular and ultrastuctureal markers. The culture of neural pre- 
cursor cells in collagen scaffold may provide a new approach to repair spinal cord injury.

\section{Materials and Methods}

\section{Human embryonic stem cell culture}

The hESC line, Royan H5, at passages 15-30 used in these experiments was first cultured on mouse embryonic fibroblasts (MEF), inactivated by mitomycin C (Sigma; M0503) (Baharvand et al., 2006). The cells were then passaged and maintained under feeder-free conditions for 2530 passages as described (Xu et al., 2005). Briefly, ideal colonies were mechanically dissected into small pieces and replated on matrigel-coated dishes and the medium changed every day. The cells were cultured in hESC medium: DMEM/F12 medium (Gibco;21331-020) supplemented with $20 \%$ knock-out serum replacement (KSR, Gibco; 10828-028), 2mM L-glutamine (Gibco; 25030-024), $0.1 \mathrm{mM} \beta$-mercaptoethanol (Sigma; M7522), 1\% nonessential amino acid (Gibco; 11140-035), 100 units $/ \mathrm{ml}$ penicillin and $100 \mu \mathrm{g} / \mathrm{ml}$ streptomycin (Gibco; 15070-063), $40 \mathrm{ng} / \mathrm{mL}$ basic-fibroblast growth factor (bFGF, Sigma; F0291) and $100 \mathrm{ng} / \mathrm{mL}$ noggin (R\&D; 1967-NG). Cells were grown in 10\% CO2 and $95 \%$ humidity and they were further passaged as small clumps every 5-6 days manually with a sterile pipette.

\section{Neural differentiation}

The differentiation procedure is outlined in Figure 1 and divided into four stages to assist in characterizing the progression of in vitro neural differentiation. After manual passage in the absence of feeder layer, $\mathrm{hESC}$ sere allowed to proliferate in hESC medium for 4-5 days (stage

\section{TABLE 1}

\section{PRIMERS USED FOR REVERSE TRANSCRIPTION-PCR ANALYSIS DURING NEURAL LINEAGE DIFFERENTIATION OF HESC}

\begin{tabular}{|c|c|c|c|}
\hline Genes & Primer Sequences (5'-3') & $\begin{array}{c}\text { Annealing } \\
\text { Temperature } \\
\text { (ํㅡ) }\end{array}$ & $\begin{array}{c}\text { Gene Bank } \\
\text { accession } \\
\text { number }\end{array}$ \\
\hline Sox1 & $\begin{array}{l}\text { CAA TGC GGG GAG GAG AAG TC } \\
\text { CTC CTC TGG ACC AAA CTG TG }\end{array}$ & 60 & 005986 \\
\hline Sox3 & $\begin{array}{l}\text { ACC TTT GTA GGC TGG GAA TCG } \\
\text { ATC ACG GCA GAA ATC ACC AAC }\end{array}$ & 64 & 005634 \\
\hline Nkx6.1 & $\begin{array}{l}\text { GTT CCT CCT CCT СCT CTT CCT C } \\
\text { AAG ATC TGC TGT CCG GAA AAA G }\end{array}$ & 58 & 006168 \\
\hline Nkx2.2 & $\begin{array}{l}\text { TGC CTC TCC TTC TGA ACC TTG } \\
\text { GCG AAA TCT GCC ACC AGT TG }\end{array}$ & 60 & 002509 \\
\hline Mnr2 & $\begin{array}{l}\text { TTG CCA TTC ACC GTC ACT TAT T } \\
\text { AAT CCA TCA GCC TTC ACC TG }\end{array}$ & 60 & 018657 \\
\hline Pax6 & $\begin{array}{l}\text { CAG CTC GGT GGT GTC TTT G } \\
\text { AGT CGC TAC TCT CGG TTT A }\end{array}$ & 63 & 000280 \\
\hline $\mathrm{Hb9}$ & $\begin{array}{l}\text { GCC TAA GAT GCC CGA CTT CAA C } \\
\text { TCC TCG TCC TCG TCC TCC TC }\end{array}$ & 63 & 005515 \\
\hline$|s| 1$ & $\begin{array}{l}\text { GAT TTC CCT ATG TGT TGG TTG C } \\
\text { CTT CCA CTG GGT TAG CCT GTA A }\end{array}$ & 60 & 002202 \\
\hline Olig2 & $\begin{array}{l}\text { CTA GGA GGC AGT GGC TTC AAG } \\
\text { CTC GCT CAC CAG TCG CTT CA }\end{array}$ & 65 & 005806 \\
\hline Lim2 & $\begin{array}{l}\text { AGG ACA GCC TGG TCT ACT GC } \\
\text { AGC TTA GCG CAG CGT TGT AG }\end{array}$ & 55 & 030657 \\
\hline Lim3 & $\begin{array}{l}\text { GGCACAGCAAGTGTCTCAAG } \\
\text { CTTGGCGGTTTCGTAGTCC }\end{array}$ & 56 & 014564 \\
\hline Nestin & $\begin{array}{l}\text { CTC TGA CCT GTC AGA AGA AT } \\
\text { CCC ACT TTC TTC CTC ATC TG }\end{array}$ & 56 & 006617 \\
\hline Oct4 & $\begin{array}{l}\text { CTT GCT GCA GAA GTG GGT GGA GGA A } \\
\text { CTG CAG TGT GGG TTT CGG GCA }\end{array}$ & 70 & 002701 \\
\hline Nanog & $\begin{array}{l}\text { CAG AAG GCC TCA GCA CCT AC } \\
\text { GTC ACT GGC AGG AGA ATT TGG }\end{array}$ & 62 & 024865 \\
\hline GAPDH & $\begin{array}{l}\text { CCA GGT GGT CTC CTC TGA CTT CAA CAG } \\
\text { AGG GTC TCT CTC TTC CTC TTG TGC TCT }\end{array}$ & 70 & 002046 \\
\hline
\end{tabular}

1). Since RA may promote caudalization and/or motoneuron specification (Li et al., 2005), we induced the neuroectodermal cells with RA $\left(4 \times 10^{-6} \mathrm{M}\right.$, Sigma; R2625) in the hESC medium without bFGF and noggin and the presence of $5 \% \mathrm{KSR}$ for six days at which time we observed columnar cells beginning to organize into rosettes. The cells were then grown without RA for another six days (stage 2) in the same medium to promote additional rosette formation without growth arrest. Then the cells were exposured to $25 \mathrm{ng} / \mathrm{ml} \mathrm{bFGF}$ for another 6 days, giving rise to what appeared to be neural tube-like structures (stage 3 ). These structures were separated manually from the surrounding flat cells with a sterile pulled-glass pipette under the phase contrast microscope (10X, Olympus, CKX41). The neural tube-like structures were then plated on laminin (5 $\mu \mathrm{g} / \mathrm{ml}$, Sigma; L2020) and poly L-ornithine (15 $\mu \mathrm{g} / \mathrm{ml}$, Sigma; P4957)coated tissue culture dishes (TPP; 93040) in neurobasal medium (Gibco; 21103-049), supplemented with 1\% N2 (Gibco; 17502-048) and 2\% B27 (Gibco; 17504-044) for up to 30 days (stage 4).

\section{Antibodies and immunocytochemistry}

Cells plated on laminin and poly L-ornithine-coated chamber slides (Nunc; 177429) were washed in PBS and fixed with 4\% paraformaldehyde (Sigma; P6148) and 0.25\% glutaraldehyde (sigma;G5882) in phosphate buffered saline (PBS) for one hour. Fixed cells were washed two times with PBS before staining. Permeabilization and blocking was carried out in a blocking buffer consisting of $0.1 \%$ Triton, $5 \%$ goat serum and $1 \mathrm{mg} / \mathrm{ml}$ bovine serum albumin (BSA; Sigma; A3311) in Tris buffer for $20 \mathrm{~min}$. Primary antibodies were applied in blocking buffer for $45 \mathrm{~min}$ at room temperature or overnight in $4^{\circ} \mathrm{C}$ and washed three times in blocking buffer before secondary antibody application. Secondary antibody, goat anti-mouse IgG conjugated-fluorescein isothiocyanate (FITC, Chemicon; AP308F), was diluted at 1:200 in blocking buffer and applied to cells for $45 \mathrm{~min}$ at room temperature. After two washes in PBS, propidium iodide $(10 \mu \mathrm{g} / \mathrm{ml})$ was applied for $10 \mathrm{~min}$ for nuclear counterstaining and cells were observed under the fluorescence microscope. For negative controls, primary antibodies were omitted and the same staining procedure was followed. Primary antibodies and dilutions used included the following: mouse anti-nestin (1:50; Chemicon; MAB5326), mouse anti-betatubulin III (1:250, Sigma; T8660), mouse anti-MAP-2 (2a+2b) (1:200, Sigma; M1406), mouse anti-synaptophysin (1:250, Sigma; S5768) and mouse anti-neurofilament protein 200 (1:50, Sigma; N5389). To estimate the efficiency of generation of neurons, we determined the number of them as a percentage of total cells in the population. Because it is difficult to accurately count the cells in three-dimensional clusters, we measured the number of positive cells after dissociation of the cell clusters. Therefore, neural tubes at the end of stage 3 were dislodged from tissue culture surface and trypsinized $(0.025 \%$ in $0.1 \%$ EDTA) to dissociate clusters into single cells. Dissociated cells were allowed to adhere to poly-ornithine/ laminin-coated glass coverslips for two weeks (stage 4), fixed, immunostained for primary antibody and counterstained with a nuclear stain propidium iodide. The percentage of putative neural cells among the total cells was obtained based on three independent experiments.

\section{Reverse transcription-polymerase chain reaction analysis}

Total RNA was extracted from cultured cells using the NucleoSpin RNA II kit (Macherey-Nagel, Düren, Germany). Prior to reverse transcription (RT), RNA samples were digested with DNase I (Fermentas; EN0521) to remove contaminating genomic DNA. Standard RT was performed using $2 \mu \mathrm{g}$ total RNA, oligo (dT)18 and the RevertAid ${ }^{\mathrm{TM}} \mathrm{H}$ Minus First Strand cDNA Synthesis kit (Fermentas; K1622) according to the manufacturer's instructions. The cDNA samples were subjected to polymerase chain reaction (PCR) amplification using human specific primers designed using different exons (Table 1). Amplification conditions were as follows: Initial denaturation at $94^{\circ} \mathrm{C}$ for $5 \mathrm{~min}$ followed by 35 cycles of denaturation at $94^{\circ} \mathrm{C}$ for $30 \mathrm{sec}$, annealing at $55-70^{\circ} \mathrm{C}$ for $45 \mathrm{sec}$ (see table for temperatures used), extension for $45 \mathrm{sec}$ at $72^{\circ} \mathrm{C}$ and a final polymerization at $72^{\circ} \mathrm{C}$ for $10 \mathrm{~min}$. The PCRs were performed in triplicate. 
The PCR products were analyzed by gel electrophoresis on $1.7 \%$ agarose and stained with ethidium bromide $(10 \mu \mathrm{g} / \mathrm{ml})$ and visualized and photographed on a UV transluminator (Uvidoc, UK).

\section{Transmission electron microscopy}

Two weeks after plating of neural tube-like structures in three dimensional collagen scaffolds, differentiated neurons were processed for ultrastructural analysis. The collagen solution consisted of $2 \mathrm{ml}$ collagen type I ( $3 \mathrm{mg} / \mathrm{ml}$, Vitrogen, Palo Alto, CA, USA), which was mixed with 250 $\mu$ l Hanks' balanced salt solution (HBSS, 10x, Gibco, 25300-054) and 250 $\mu$ l sodium bicarbonate $(0.1 \mathrm{M})$ in the proportions of $8: 1: 1(\mathrm{v} / \mathrm{v} / \mathrm{v})$. The mixture supplemented with the medium of stage 4 in the proportions of $1: 1$ (v/v). Finally, $5 \mu \mathrm{g} / \mathrm{ml}$ laminin and $15 \mu \mathrm{g} / \mathrm{ml}$ poly-L-ornithine were added. The concentration of collagen was selected based on results published for neural cell growth in collagen gel where it was reported that optimal growth occurred in gels prepared below $0.5 \mathrm{mg} / \mathrm{ml}$ (Baldwin et al., 1996, Mahoney et al., 2006). The samples were fixed using $2 \%$ glutaraldehyde in $0.1 \mathrm{M}$ PBS ( $\mathrm{pH} 7.4)$ for $2 \mathrm{~h}$. After washing for $2 \times 30 \mathrm{~min}$, the samples were fixed with $1 \%$ osmium tetroxide for $1.5 \mathrm{~h}$. The samples were washed 3 times in distilled water ( 5 min each) and dehydrated in an ethanol series; $30 \%, 50 \%, 70 \%, 90 \%$ and $95 \%$ for $15 \mathrm{~min}$ each and then 3 times (15 min each) in $100 \%$ ethanol. Infiltration into Spurr's resin was achieved by an ethanol/resin series: first in 50:50 (2 h), then $100 \%$ resin $(2 \mathrm{~h})$, after that in $100 \%$ resin (overnight) and again in fresh resin $(2 \mathrm{~h})$. The samples were then embedded in moulds containing $100 \%$ resin and polymerized at $70^{\circ} \mathrm{C}$ overnight. After polymerization, the sections of about $80 \mathrm{~nm}$ were cut and stained with lead citrate for $8 \mathrm{~min}$. Micrographs of transverse sections of the cells were taken on plate films on a Zeiss EM900 (Germany) transmission electron microscope (TEM).

\section{Acknowledgement}

We gratefully thank Dr. Philip H. Schwartz, Children's Hospital of Orange County Research Institute, USA, for his critical reading and helpful comments on the manuscript. We also acknowledge Abbas Piriaei and Adeleh Taei for technical assistance. The authors would like to dedicate this paper to the memory of Dr. Saeid Kazemi Ashtiani. This project was supported by SBDC of Royan institute and industrial deve/opment and renovation organization of Iran.

\section{References}

ALLEGRUCCI, C., DENNING, C., PRIDDLE, H. and YOUNG, L. (2004). Stem-cell consequences of embryo epigenetic defects. Lancet 364: 206-8.

ARBER, S., HAN, B., MENDELSOHN, M., SMITH, M., JESSELL, T.M. and SOCKANATHAN, S. (1999). Requirement for the homeobox gene Hb9 in the consolidation of motor neuron identity. Neuron 23: 659-74.

BAHARVAND, H. (2006). Embryonic Stem Cells: Establishment, maintenance and differentiation. In Embryonic Stem Cell Research, (ed. GRIER, E. V.). Nova Science Publishers, Inc., USA. pp.1-63

BAHARVAND, H., KAZEMI ASHTIANI S, TAEE A, MASSUMI M, REZAZADEH VALOJERDI M, EFTEKHARI YAZDI P, ZAREI MORADI S and FARROKHI A. (2006). Generation of new human embryonic stem cell lines with diploid and triploid karyotypes. Dev. Growth. Differ. 48: 117-28.

BAIN, G., RAY, W.J., YAO, M. and GOTTLIEB, D.I. (1996). Retinoic acid promotes neural and represses mesodermal gene expression in mouse embryonic stem cells in culture. Biochem. Biophys. Res. Commun. 223: 691-4.

BALDWIN, S.P., KREWSON, C.E. and SALTZMAN, W.M. (1996). PC12 cell aggregation and neurite growth in gels of collagen, laminin and fibronectin. Int. J. Dev. Neurosci. 14: 351-64.

CARPENTER, M.K., INOKUMA, M.S., DENHAM, J., MUJTABA, T., CHIU, C.P. and RAO, M.S. (2001). Enrichment of neurons and neural precursors from human embryonic stem cells. Exp. Neurol. 172: 383-97.

CAVODEASSI, F., DIEZ DEL CORRAL, R., CAMPUZANO, S. and DOMINGUEZ, M. (1999).'Compartments and organising boundaries in the Drosophila eye: the role of the homeodomain Iroquois proteins. Development 126: 4933-42.
CHEN, Y., HE, Z.X., LIU, A., WANG, K., MAO, W.W., CHU, J.X., LU, Y., FANG, Z.F., SHI, Y.T., YANG, Q.Z. et al. (2003). Embryonic stem cells generated by nuclear transfer of human somatic nuclei into rabbit oocytes. Cell Res. 13: 251-63.

DANG, S.M., KYBA, M., PERLINGEIRO, R., DALEY, G.Q. and ZANDSTRA, P.W. (2002). Efficiency of embryoid body formation and hematopoietic development from embryonic stem cells in different culture systems. Biotechnol. Bioeng. 78: 442-53.

GERRARD, L., RODGERS L and CUI, W. (2005). Differentiation of human embryonic stem cells to neural lineages in adherent culture by blocking bone morphogenetic protein signaling. Stem Cel/s. 23: 1234-41.

HAY, D.C., SUTHERLAND, L., CLARK, J. and BURDON, T. (2004). Oct-4 knockdown induces similar patterns of endoderm and trophoblast differentiation markers in human and mouse embryonic stem cells. Stem Cells 22: 225-35.

ITSYKSON, P., ILOUZ N, TURETSKY T, GOLDSTEIN R.S, PERA M.F, FISHBEIN I, SEGAL M and REUBINOFF. B.E. (2005). Derivation of neural precursors from human embryonic stem cells in the presence of noggin. Mol. Cel/ Neurosci. 30: 24-36.

JOOSTEN, E.A., VELDHUIS, W.B. and HAMERS, F.P. (2004). Collagen containing neonatal astrocytes stimulates regrowth of injured fibers and promotes modest locomotor recovery after spinal cord injury. J. Neurosci. Res. 77: 127-42.

KLAPKA, N. and MULLER, H.W. (2006). Collagen matrix in spinal cord injury. J. Neurotrauma 23: 422-35.

LI, X.J., DU, Z.W., ZARNOWSKA, E.D., PANKRATZ, M., HANSEN, L.O., PEARCE, R.A. and ZHANG, S.C. (2005). Specification of motoneurons from human embryonic stem cells. Nat. Biotechnol. 23: 215-21.

LI, X.J. and ZHANG, S.C. (2006). In vitro differentiation of neural precursors from human embryonic stem cells. Methods Mol. Biol. 331: 169-77.

LIOUR, S.S., KRAEMER, S.A., DINKINS, M.B., SU, C.Y., YANAGISAWA, M. and YU, R.K. (2006). Further characterization of embryonic stem cell-derived radial glial cells. Glia 53: 43-56.

MAHONEY, M.J., KREWSON, C., MILLER, J. and SALTZMAN, W.M. (2006) Impact of cell type and density on nerve growth factor distribution and bioactivity in 3-dimensional collagen gel cultures. Tissue Eng. 12: 1915-27.

MEIRMANOV, S., NAKASHIMA, M., ROGOUNOVITCH, T., FUKUDA, E., NAKAYAMA, T., SATO, F. and SEKINE, I. (2003). Small cell carcinoma of the endometrium: report of a case with analysis of $\mathrm{Wnt} /$ beta-catenin pathway. Pathol. Res. Pract. 199: 551-8.

MIZUGUCHI, R., SUGIMORI, M., TAKEBAYASHI, H., KOSAKO, H., NAGAO, M., YOSHIDA, S., NABESHIMA, Y., SHIMAMURA, K. and NAKAFUKU, M. (2001). Combinatorial roles of olig2 and neurogenin2 in the coordinated induction of pan-neuronal and subtype-specific properties of motoneurons. Neuron31:75771.

MIZUSEKI, K., SAKAMOTO, T., WATANABE, K., MUGURUMA, K., IKEYA, M., NISHIYAMA, A., ARAKAWA, A., SUEMORI, H., NAKATSUJI, N., KAWASAKI, H. et al. (2003). Generation of neural crest-derived peripheral neurons and floor plate cells from mouse and primate embryonic stem cells. Proc. Natl. Acad. Sci. USA 100: 5828-33.

NAT, R., NILBRATT, M., NARKILAHTI, S., WINBLAD, B., HOVATTA, O. and NORDBERG, A. (2007). Neurogenic neuroepithelial and radial glial cells generated from six human embryonic stem cell lines in serum-free suspension and adherent cultures. Glia 55: 385-99.

NIWA, H., MIYAZAKI, J. and SMITH, A.G. (2000). Quantitative expression of Oct$3 / 4$ defines differentiation, dedifferentiation or self-renewal of ES cells. Nat. Genet. 24: 372-6.

NOVITCH, B.G., CHEN, A.I. and JESSELL, T.M. (2001). Coordinate regulation of motor neuron subtype identity and pan-neuronal properties by the bHLH repressor Olig2. Neuron 31: 773-89.

O'SHAUGHNESSY, T.J., LIN, H.J. and MA, W. (2003). Functional synapse formation among rat cortical neurons grown on three-dimensional collagen gels. Neurosci. Lett. 340: 169-72.

OKABE, S., FORSBERG-NILSSON, K., SPIRO, A.C., SEGAL, M. and MCKAY, R.D. (1996). Development of neuronal precursor cells and functional postmitotic neurons from embryonic stem cells in vitro. Mech. Dev. 59: 89-102.

PERRIER, A.L., TABAR, V., BARBERI, T., RUBIO, M.E., BRUSES, J., TOPF, N., HARRISON, N.L. and STUDER, L. (2004). Derivation of midbrain dopamine neurons from human embryonic stem cells. Proc. Natl. Acad. Sci. USA 101: 12543-8. 
PEVNY, L.H., SOCKANATHAN, S., PLACZEK, M. and LOVELL-BADGE, R. (1998). A role for SOX1 in neural determination. Development 125: 1967-78.

REUBINOFF, B.E., PERA, M.F., FONG, C.Y., TROUNSON, A. and BONGSO, A. (2000). Embryonic stem cell lines from human blastocysts: somatic differentiation in vitro. Nat. Biotechnol. 18: 399-404.

SANDER, M., PAYDAR, S., ERICSON, J., BRISCOE, J., BERBER, E., GERMAN, M., JESSELL, T.M. and RUBENSTEIN, J.L. (2000). Ventral neural patterning by Nkx homeobox genes: Nkx6.1 controls somatic motor neuron and ventral interneuron fates. Genes Dev. 14: 2134-9.

SCHULDINER, M., YANUKA, O., ITSKOVITZ-ELDOR, J., MELTON, D.A. and BENVENISTY, N. (2000). Effects of eight growth factors on the differentiation of cells derived from human embryonic stem cells. Proc. Natt. Acad. Sci.USA 97: 11307-12.

SHIMOZAKI, K., NAKASHIMA, K., NIWA, H. and TAGA, T. (2003). Involvement of Oct3/4 in the enhancement of neuronal differentiation of ES cells in neurogenesisinducing cultures. Development 130: 2505-12.

SHIN, S., MITALIPOVA M, NOGGLE S, TIBBITTS D, VENABLE A, RAO R and STICE, S.L. (2006). Long-term proliferation of human embryonic stem cellderived neuroepithelial cells using defined adherent culture conditions. Stem Cells. 24: 125-38.

SHIOTSUGU, J., KATSUYAMA, Y., ARIMA, K., BAXTER, A., KOIDE, T., SONG, J., CHANDRARATNA, R.A. and BLUMBERG, B. (2004). Multiple points of interaction between retinoic acid and FGF signaling during embryonic axis formation. Development 131: 2653-67.

THOMSON, J.A., ITSKOVITZ-ELDOR, J., SHAPIRO, S.S., WAKNITZ, M.A., SWIERGIEL, J.J., MARSHALL, V.S. and JONES, J.M. (1998). Embryonic stem cell lines derived from human blastocysts. Science 282: 1145-7.
TROPEPE, V., HITOSHI, S., SIRARD, C., MAK, T.W., ROSSANT, J. and VAN DER KOOY, D. (2001). Direct neural fate specification from embryonic stem cells: a primitive mammalian neural stem cell stage acquired through a default mechanism. Neuron 30: 65-78.

WICHTERLE, H., LIEBERAM, I., PORTER, J.A. and JESSELL, T.M. (2002). Directed differentiation of embryonic stem cells into motor neurons. Cel/110: 385-97.

WU, P., TARASENKO, Y.I., GU, Y., HUANG, L.Y., COGGESHALL, R.E. and YU, Y. (2002). Region-specific generation of cholinergic neurons from fetal human neural stem cells grafted in adult rat. Nat. Neurosci. 5: 1271-8.

XU, R.H., PECK, R.M., LI, D.S., FENG, X., LUDWIG, T. and THOMSON, J.A. (2005). Basic FGF and suppression of BMP signaling sustain undifferentiated proliferation of human ES cells. Nat. Methods 2: 185-190.

YAO, S., CHEN S, CLARK J, HAO E, BEATTIE G.M, HAYEK A and DING S. (2006). Long-term self-renewal and directed differentiation of human embryonic stem cells in chemically defined conditions. Proc. Natl. Acad. Sci. USA 103: 6907-12.

YING, Q.L., STAVRIDIS, M., GRIFFITHS, D., LI, M. and SMITH, A. (2003). Conversion of embryonic stem cells into neuroectodermal precursors in adherent monoculture. Nat. Biotechnol. 21: 183-6.

ZHANG, S.C., WERNIG, M., DUNCAN, I.D., BRUSTLE, O. and THOMSON, J.A. (2001). In vitro differentiation of transplantable neural precursors from human embryonic stem cells. Nat. Biotechnol. 19: 1129-33.

Received: 12th February 2007 Reviewed by Referees: 29th March 2007 Modified by Authors and Accepted for Publication: 26th April 2007 Published Online: 25th June 2007 
Related, previously published Int. J. Dev. Biol. articles

See our recent Special Issue on Mammalian Reproduction \& Development edited by Brigid Hogan at: http:// www.ijdb.ehu.es/web/contents.php?vol=45\&issue=3

Effects of growth factors on the differentiation of neural crest cells and neural crest cell-derivatives. B K Hall and S Ekanayake

Int. J. Dev. Biol. (1991) 35: 367-387

Differentiation of human embryonic stem cells into hepatocytes in 2D and 3D culture systems in vitro Hossein Baharvand, Seyed M. Hashemi, Saeid Kazemi Ashtiani and Ali Farrokhi Int. J. Dev. Biol. (2006) 50: 645-652

Selection of reference genes in mouse embryos and in differentiating human and mouse ES cells Erik Willems, lleana Mateizel, Caroline Kemp, Greet Cauffman, Karen Sermon and Luc Leyns Int. J. Dev. Biol. (2006) 50: 627-635

Expression of regulatory genes for pancreas development during murine embryonic stem cell differentiation Josué K. Mfopou, Erik Willems, Luc Leyns and Luc Bouwens Int. J. Dev. Biol. (2005) 49: 915-922

Embryonic stem cells differentiate into insulin-producing cells without selection of nestin-expressing cells Przemyslaw Blyszczuk, Christian Asbrand, Aldo Rozzo, Gabriela Kania, Luc St-Onge, Marjan Rupnik and Anna M. Wobus Int. J. Dev. Biol. (2004) 48: 1095-1104

The generation of insulin-producing cells from embryonic stem cells - a discussion of controversial findings Gabriela Kania, Przemyslaw Blyszczuk and Anna M. Wobus Int. J. Dev. Biol. (2004) 48: 1061-1064

Quantitative gene expression profiling reveals a fetal hepatic phenotype of murine ES-derived hepatocytes. Andrea Jochheim, Tina Hillemann, Gabriela Kania, Jennifer Scharf, Masoumeh Attaran, Michael P Manns, Anna M Wobus and Michael Ott

Int. J. Dev. Biol. (2004) 48: 23-29

Targeted disruption of fibroblast growth factor receptor-1 blocks maturation of visceral endoderm and cavitation in mouse embryoid bodies.

Milan Esner, Jiri Pachernik, Ales Hampl and Petr Dvorak

Int. J. Dev. Biol. (2002) 46: 817-825

Embryonic stem cell differentiation and the analysis of mammalian development.

Stephen J Rodda, Steven J Kavanagh, Joy Rathjen and Peter D Rathjen

Int. J. Dev. Biol. (2002) 46: 449-458

DNA methylation of the U2af1-rs1 gene in embryonic stem cells and embryonal carcinoma cells after RA-induced differentiation and apoptosis

N Andollo, MD Boyano, A Asumendi, MM Zalduendo, J Arechaga

Int. J. Dev. Biol. (2001) 45: S149-S150

Lithium influences differentiation and tissue-specific gene expression of mouse embryonic stem (ES) cells in vitro. M M Schmidt, K Guan and A M Wobus Int. J. Dev. Biol. (2001) 45: 421-429

Bone morphogenetic proteins (BMPs) induce epithelial differentiation of NT2D1 human embryonal carcinoma cells.

A Caricasole, D Ward-van Oostwaard, L Zeinstra, A van den Eijnden-van Raaij and C Mummery Int. J. Dev. Biol. (2000) 44: 443-450

The generation and in vivo differentiation of murine embryonal stem cells genetically null for either $\mathrm{N}$-cadherin or $\mathrm{N}$ - and P-cadherin.

R Moore, G L Radice, M Dominis and R Kemler

Int. J. Dev. Biol. (1999) 43: 831-834 


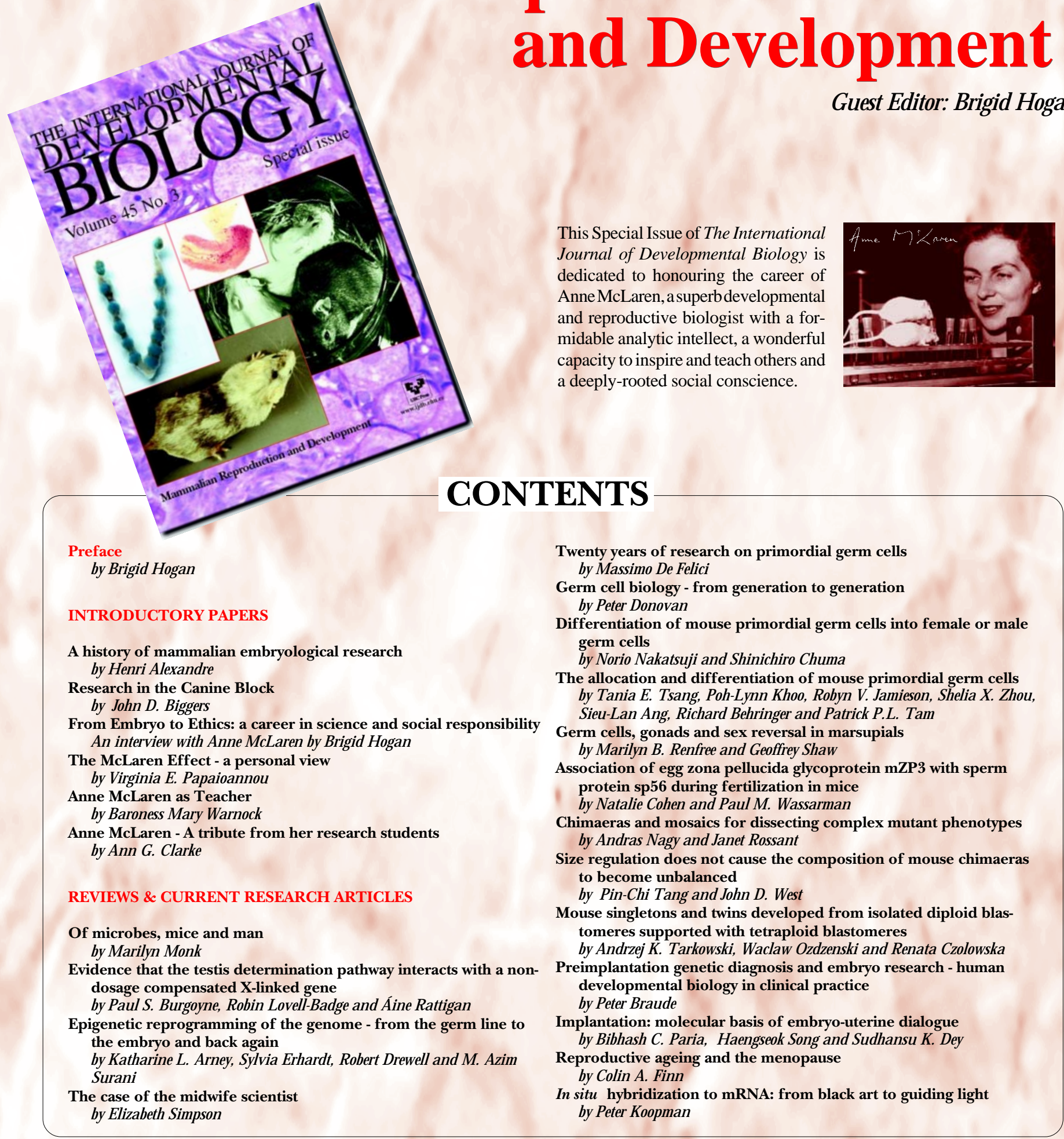

\section{ORDER FORM}

I would like to order ___ cop(y/ies) of the Int. J. Dev. Biol. Special Issue “Mammalian Reproduction and Development” (Vol. 45, № 3) at US\$ 90 or Euro $€ 70$ per copy (including post and packaging). Total to be charged: US\$ / Euro $€$ (please specify currency)

\section{ORDER BY}

$\checkmark$ Web: http://www.intjdevbiol.com

$\checkmark$ E-mail: ijdb@ehu.es (include the information indicated above)

$\checkmark$ FAX: +34-94-601-3266

$\checkmark$ POST: to the address shown beside
The International Journal of Developmental Biology

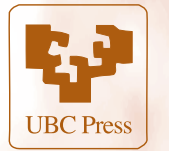

UBC Press - Faculty of Medicine

University of the Basque Country, E-48940 Leioa, Vizcaya,

SPAIN 